„Przekłady Literatur Słowiańskich”. T. 9, cz. 3 ISSN 2353-9763 (wersja elektroniczna)

DOI 10.31261/PLS.2019.09.03.20

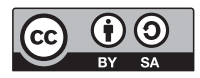

\title{
Bibliografia przekładów literatury słoweńskiej w Polsce w 2017 roku
}

\author{
The Bibliography of Translations \\ of Slovenian Literature in Poland in 2017
}

\section{Monika Gawlak}

iD https://orcid.org/0000-0002-0002-5107

UNIVERSITY OF SILESIA IN KATOWICE monika.gawlak@us.edu.pl 


\section{Publikacje książkowe}

1. Flisar Evald: Opazovalec / Obserwator.

Tłum. Marlena Gru d a. Warszawa, Wydawnictwo Ezop, 2017, 396 s.

[proza].

2. Flisar Evald: Na zlati obali / Na złotym wybrzeżu.

Tłum. Marlena Gru d a. Warszawa, Wydawnictwo Ezop, 2017, 314 s.

[proza].

3. Gorečan Katja: Hana is vse ostalo / Hana i wszystko inne.

Tłum. Miłosz B i e d r z y c k i. Gdańsk, Instytut Kultury Miejskiej, 2017,

58 s. [poezja].

${ }^{* * *}$ (sosed / je veliko let nazaj...) /

${ }^{* * *}$ (sąsiad / wiele lat temu...), s. 19

Dolganoč v gozdu sanja / Długanoc śni w lesie, s. 13-16

Hana in menstruacija / Hana i miesiączka, s. 8-9

Hana in poezija (Hani sen e da več) /

Hana i poezja (Hanie się odechciewa), s. 5-6

Hana in svet / Hana $i$ świat, 10-11

Hana na stranišču / Hana w ubikacji, s. 7

Rojstvo mrtvega otroka /

Narodziny nieżywego dziecka, s. 17-18

Uvod / Wstęp, s. 12.

4. Koren Majda: Skuhaj mi pravljico / Ugotuj mi bajkę.

Tłum. Mariusz B i e d r z y cki. Oprac. graficzne Agata D u d e k.

Warszawa, Wydawnictwo Ezop, 2017, 32 s. [literatura dla dzieci].

5. Kraljič Helena: Imam disleksijo / Mam dysleksję.

Tłum. Aleksandra B r o ż e k-S a l a. Ilustracje Maja L u b i.

Warszawa, Wydawnictwo Piętka, 2017, 26 s. [literatura dla dzieci].

6. Kraljič Helena: Imam downov sindrom / Mam zespót Downa.

Tłum. Aleksandra B r o ż e k-S a l a. Ilustracje Maja L u b i.

Warszawa, Wydawnictwo Piętka, 2017, 25 s. [literatura dla dzieci].

7. Kraljič Helena: Larina skrivnost / Sekret Laury.

Tłum. Aleksandra B r o ż e k-S a l a. Ilustracje Maja L u bi.

Warszawa, Wydawnictwo Piętka, 2017, 17 s. [literatura dla dzieci].

8. Kraljič Helena: Žan je drugačen / Janek jest inny: historia chłopca $z$ autyzmem.

Tłum. Aleksandra B r o ż e k-S a l a. Ilustracje Maja L u b i.

Warszawa, Wydawnictwo Piętka, 2017, 26 s. [literatura dla dzieci].

9. Novak Maja: Cimre / Współlokatorki.

Tłum. Kinga D y s z e r o w i c z. London, Sarem, 2017, 259 s. [proza]. 
10. Pregl Sanja: Ljubezni je za vse dovolj / Miłości starczy dla wszystkich. Tłum. Aleksandra B r o ż e k-S a l a. Ilustracje Maja L u b i.

Warszawa, Wydawnictwo Piętka, 2017, 26 s. [literatura dla dzieci].

11. Pregl Sanja: Si, čeprav te ni / Odszedłeś, ale wciąż tu jesteś.

Tłum. Aleksandra B r o ż e k-S a l a. Ilustracje Maja L u b i.

Warszawa, Wydawnictwo Piętka, 2017, 26 s. [literatura dla dzieci].

\section{Publikacje w czasopismach}

1. „Wyspa” 2017, nr 4.

Prešeren France

Zdravljica / Toast.

Tłum. Seweryn Pollak, s. 72 [poezja].

\section{Pungartnik Marjan}

Karyntia

Obraz olejny na płótnie

Orion / Orion.

Tłum. Katarina Š a l a m u n-B i e d r z y c k a, s. 37-39

[poezja].

MONIKA GAWLAK | dr, literaturoznawczyni, słowenistka, starszy wykładowca w Zakładzie Teorii Literatury i Translacji w Instytucie Filologii Słowiańskiej Uniwersytetu Śląskiego w Katowicach. Bada XX-wieczną literaturę słoweńską oraz jej polskie przekłady. Przetłumaczyła z języka słoweńskiego teksty literackie i naukowe (m.in. poezję Barbary Simoniti; prozę Mihy Mazziniego, Polony Glavan, Roberta Šabca; artykuły Ireny Novak-Popov, Nikolaja Ježa, Any Makuc). Publikowała w Polsce i za granicą, m.in. w „Studium”, „Opcjach”, „Tekstualich”, „Przekładach Literatur Słowiańskich”, „Novej reviji”. Współorganizowała liczne wydarzenia promujące słoweńską kulturę w Polsce. Jest autorką monografii pt. Świat poetycki Gregora Strnišy (2012) oraz artykułów, m.in.: Tożsamość Čefura w przekładzie powieści Gorana Vojnovicia pt. „Čefurji raus!” w tłumaczeniu Tomasza Łukaszewicza (2012); Prevodi slovenske proze na Poljskem po letu 1991 (2014); O przekładzie tytułu (na podstawie prozy słoweńskiej) (2015). 